\title{
Phase Changes in Arrhenius Plots on NMR Relaxation Times for Various Organs of Crop Plants Exposed to Temperature Stresses
}

\author{
Mari Iwaya-Inoue, Hiroshi Nonami* and Masataka Fukuyama \\ Laboratory of Crop Science, Department of Plant Resources, Faculty of Agriculture, \\ Kyushu University, Hakozaki, Fukuoka 812-8581, Japan \\ * Plant Biophysics/Biochemistry Research Laboratory, Faculty of Agriculture, \\ Ehime University, Matsuyama 790-8566, Japan
}

(Received December 5, 2003)

Arrhenius plots of dynamic states of water in various crop plant organs exposed to cold or heat stress were studied by using ${ }^{1} \mathrm{H}-\mathrm{NMR}$. In chilling sensitive plants, phase transition in NMR spin-lattice relaxation time $\left(T_{1}\right)$ occurred at $7.5^{\circ} \mathrm{C}$ and at $12.5^{\circ} \mathrm{C}$ in $V i g n a$ radiata and $V$. mungo hypocotyls, respectively, while that in spin-spin relaxation time $\left(T_{2}\right)$ occurred at $13.5^{\circ} \mathrm{C}$ in sweet potato tubers. On the other hand, phase transition in $T_{1}$ occurred at $0^{\circ} \mathrm{C}$ in both leaves and roots of perennial ryegrass and pea epicotyls. Prolongation of $T_{1}$ was observed after the break point in these species. Furthermore, phase changes in $T_{2}$ of the ryegrass leaves and roots occurred at $-20^{\circ} \mathrm{C}$ and $-10^{\circ} \mathrm{C}$, respectively. Judging from electrolyte leakage and viability test as well as $T_{2}$, both vacuolar and cytoplasmic compartments froze between -20 and $-25^{\circ} \mathrm{C}$ in the leaves while the freezing in the root tissues occurred between -10 and $-15^{\circ} \mathrm{C}$ in ryegrass. Therefore, supercooling ability of the ryegrass organs were especially detected by $T_{2}$. On the other hand, adaptation to heat stress was clearly shown by $T_{1}$ while heat-denature was shown by a marked decrease in $T_{2}$. From these results, the phase transition temperatures were closely correlated their stress sensitivity, especially acclimation to temperatures was detectable by $T_{1}$ while critical temperature by $T_{2}$. In conclusion, analysis of Arrhenius plots of $T_{1}$ and $T_{2}$ in plant organs provided sensitive and non-invasive way for evaluating both primary and lethal responses to the temperature stresses.

Keywords : Arrhenius plots, ${ }^{1} \mathrm{H}-\mathrm{NMR}$ relaxation times $\left(T_{1}, T_{2}\right)$, molecular dynamics of water, temperature stresses, water compartments

\section{INTRODUCTION}

Environmental stresses dramatically affect plant survival and productivity. Different strategies are required for protection against transient stresses. Many plants acclimate to cold and/or heat stress (Sabehat et al., 1998; Thomashow, 1999 references therein). Therefore, it is important to select cold- or heat-tolerant crop plants for adaptation to cultivate in various climate regions. For temperature-stressed studies in plants, a phase transition has been shown in Arrhenius plots of membrane lipid (Lyons and Raison, 1970; Lyons, 1973 ; Steponkus, 1981 ; Martin, 1986 ; Wilson, 1987 ; Vonwiren et al., 1998) and a variety of biological reaction

Corresponding author: Mari Iwaya-Inoue, fax : +81-92-642-2825, e-mail : mariino@agr.kyushu-u.ac.jp 
rates (Casado and Heredia, 1999 ; Queiroz et al., 2000; Schreiber, 2001, 2002). Non-linear temperature dependency or the presence of discontinuity has been seen as diagnostics of phase transitions of membrane lipid. Although mechanisms of thermo-tolerance in plants have been extensively studied, little is known about dynamic states of water which affect cellular metabolism. The physical state of water in plant cells is also a subject of interest relative to plant cold hardiness (Levitt, 1980). Many metabolic processes such as enzymatic reactions, transportation and accumulation of materials occur in cytosol, and thus water in living tissues is considered to play an important role in their physiological condition. Water plays an important role not only as a solvent for biochemical reactions, but also as a stabilizer of macromolecular structure. Nuclear magnetic resonance (NMR) of water protons provides a method of nondestructive research on water and water interactions in biological systems (Budinger and Lauterbur, 1984; Ishida et al., 2000 ; Ionenko and Anisimov, 2001; Van der Weerd et al., 2002). The degree of physiological activity in the tissue reflects the level of water binding. Since the mobility and characteristics of cell-associated water are closely related to the condition of the cells, NMR images represent physiological maps of the plant tissues (Kano et al., 1997 ; Ishida et al., 2000). ${ }^{1} \mathrm{H}$-NMR spin-lattice $\left(T_{1}\right)$ and spin-spin $\left(T_{2}\right)$ relaxation times are used as indicators of dynamic states of water in biological tissues since they reflect the motion of water molecules. The magnitude of the signal following excitation recovers as a function of $T_{1}$ and the echo signal declines with that of $T_{2}$ (Farrar and Becker, 1971). Furthermore, $T_{1}$ and $T_{2}$ of water protons were applied to the studies of higher plant tissues exposed to thermal stresses (Kaku et al., 1985; Abass and Rajashekar, 1991; Iwaya-Inoue et al., 1993 ; Caldwell et al., 1997 ; Yoshida et al., 1997 ; Maheswari et al., 1999 ; Van der Weerd et al., 2002).

In this study the temperature dependencies of $T_{1}$ and $T_{2}$ of water protons in various organs such as hypocotyls, epicotyls, leaves, roots and tubers were determined in various plants such as pea plants, mung bean, black mappe, pasture plants (perennial ryegrass and tall fescue) and sweet potato when they were exposed to chilling, freezing or heat stress. Furthermore, we used ${ }^{1} \mathrm{H}-\mathrm{NMR}$ to address the possibility of the early identification of physiological changes in these crop plants subjected to temperature stresses.

\section{CHANGES IN NMR RELAXATION TIME $\left(T_{1}\right)$ IN VARIOUS PLANT ORGANS EXPOSED TO CHILLING STRESS}

Temperature dependencies of Arrhenius plots of NMR spin-lattice relaxation time $\left(T_{1}\right)$ and spin-spin relaxation time $\left(T_{2}\right)$, indicating dynamic states of water, were determined in various plant organs. A ${ }^{1} \mathrm{H}-\mathrm{NMR}$ spectrometer with a magnet operating at $20 \mathrm{MHz}$ or 25 $\mathrm{MHz}$ for ${ }^{1} \mathrm{H}$ was used for the measurements of $T_{1}$ and $T_{2}$. For a cold treatment, a probe temperature was controlled by a connected thermostat to the sample chamber of the spectrometer using $\mathrm{LN}_{2}$. For $T_{1}$ measurements, the saturation recovery method $\left(90^{\circ}-\tau-90^{\circ}\right.$ pulse sequence) or inversion recovery method $\left(180^{\circ}-\tau-90^{\circ}\right.$ pulse sequence) was used (Kaku and Iwaya-Inoue, 1988 ; Iwaya-Inoue et al., 2004a, 2004b).

A question of "break" or "straight" in Arrhenius plots is fairly dependent on the validity of the model selection in the statistical analysis, and AIC (Akaike's Information Criterion) method is applicable as a useful statistical procedure to give the practical standard for the resolution of the problem of the "use" or "misuse" of Arrhenius plots in stress physiology of plants (Akaike, 1971; Iwaya-Inoue et al., 1989). Break points determined with statistical models occurred at about $7.5^{\circ} \mathrm{C}$ for mung bean (Vigna radiata [L.] Wilczek) and at about $12.5^{\circ} \mathrm{C}$ for black mappe ( $V$. mungo [L.] Hopper) in temperatures ranging from 20 to $0^{\circ} \mathrm{C}$ in $2.5^{\circ} \mathrm{C}$ steps (Table 1 ). On the other hand, $T_{1}$ values in epicotyls of chilling-insensitive pea 


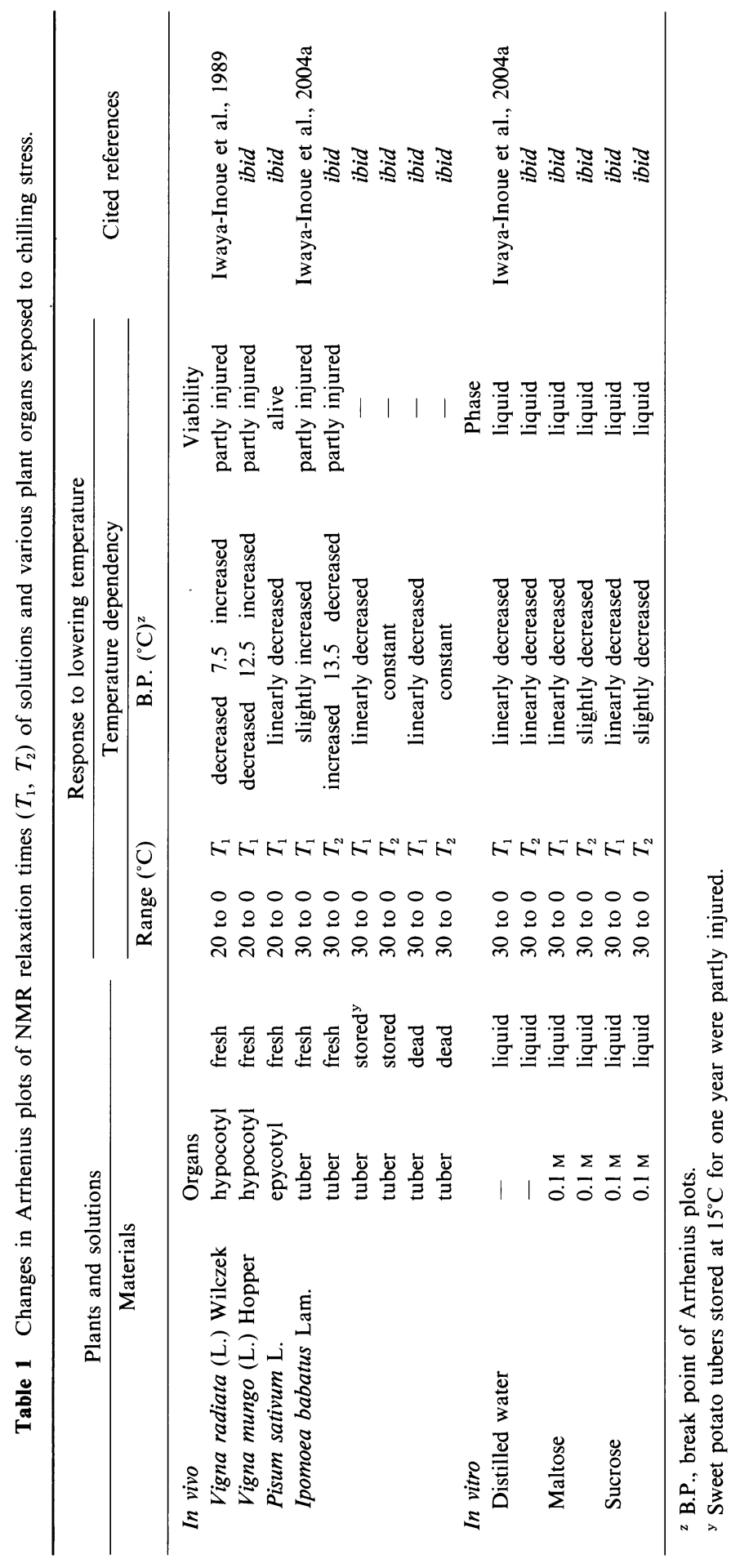


(Pisum sativum L. cv. Alaska) plants linearly depended on temperature ranging from 20 to 0 ${ }^{\circ} \mathrm{C}$. In addition, Arrhenius plots of the $T_{1}$ in leaves of tomato (Lycopersicum esculentum Mill. var. cerasiforme cv. Minicarol) and cucumber (Cucumis sativus L. cv. Ochiai) indicated biphasic with temperature drop from 20 to $0^{\circ} \mathrm{C}$ (Iwaya-Inoue et al., 2002). "Breaks" in Arrhenius plots of $T_{1}$ of fresh leaves in tomato and cucumber occurred at about $12.5^{\circ} \mathrm{C}$ and 10 ${ }^{\circ} \mathrm{C}$, respectively, while those of chilling-insensitive clone of gloxinia (Sinningia speciosa hybrids) indicated no break point during the same process. The phase change closely reflected their chilling sensitivity. From these results, it would be pointed out that the phase change in the chilling process suggests a much earlier symptom for primary response to chilling stress.

However, $T_{1}$ in sweet potato (Ipomoea babatus Lam. cv. Koganesengan) fresh tubers kept constant levels or slightly increased from 30 to $0^{\circ} \mathrm{C}$ and the relaxation behavior was markedly different from those in seedlings of the other species described above. The water content of sweet potato tuber tissues was about 65\% (Iwaya-Inoue et al., 2004a), whereas the water contents of the others were over $90 \%$ (Iwaya-Inoue et al., 1993, 2003b, 2004b). The different $T_{1}$ characteristics between tubers and hypocotyls were due to the water content. In distilled water, $T_{1}$ linearly decreased with decreases in temperature. Sugar solutions adjusted to the similar concentrations in fresh sweet potato tubers were prepared. $T_{1}$ of $0.1 \mathrm{M}$ sucrose and 0.1 $M$ maltose solutions linearly decreased with a decrease in temperature. The different NMR relaxation behaviors in the crop plants would be attributable to cell structure and cellular constitution as well as the water content. Thus, the structure of water would be altered by such physiological or pathological disturbance.

\section{CHANGES IN WATER COMPARTMENTS DETERMINED BY $T_{1}$ IN ORGANS EXPOSED TO CHILLING STRESS}

Perennial ryegrass (Lolium perenne L. cv. Friend) is widely cultivated as a pasture plant in cool temperate region (Waller and Sale, 2001 ; Ebdon et al., 2002). $T_{1}$ s in leaves and roots of 6-week-old ryegrass linearly decreased with a temperature drop from 20 to $0^{\circ} \mathrm{C} \mathrm{(Fig.} \mathrm{1,} \mathrm{Table}$ 2). Furthermore, $T_{1}$ values in seedlings of chilling-insensitive pea (Pisum sativum L. cv. Alaska) linearly depended on temperature ranging from 20 to $0^{\circ} \mathrm{C}$ (Iwaya-Inoue et al., 1989). Water in plant tissues was often characterized by different proton relaxation times (Ishida et al., 1987 ; Isobe et al., 1999 ; Iwaya-Inoue and Nonami, 2003). It is generally accepted that cellular water exists in two to three components, which are shown by NMR relaxation times. In plant tissues, these water components consist of three states of water, i.e., free water, loosely bound water and tightly bound water (Iwaya-Inoue et al., 2004b references therein). The three compartmentation of water originally identified from the vacuole, cytoplasm, and cell wall/extracellular space (apoplast), is reflected by different relaxation times in the parenchyma tissue (Snaar and Van As, 1992; Hills and Remigereau, 1997). In morning glory (Pharbitis nil Chois.) seeds, three components of water fractions characterized by different $T_{1} \mathrm{~s}$ and chemical shifts were observed (Isobe et al., 1999).

$T_{1}$ values of two water components in the ryegrass leaves were constant or linearly decreased until $0^{\circ} \mathrm{C}$ while $T_{1}$ of long fraction gradually increased below $0^{\circ} \mathrm{C}$. The relative value of signal intensity in all leaves tested was almost constant during the experiment between 20 and about $-12.5^{\circ} \mathrm{C}$. On the other hand, $T_{1}$ values of two fractions in roots linearly decreased, and the relative value of signal intensity did not change between 20 and $0^{\circ} \mathrm{C}$. "Breaks" in Arrhenius plots of $T_{1}$ of perennial ryegrass leaves occurred at $0^{\circ} \mathrm{C}$ followed by prolongation in $T_{1}$. The phase change in $T_{1}$ might have responded to a physiological change as a primary event. 


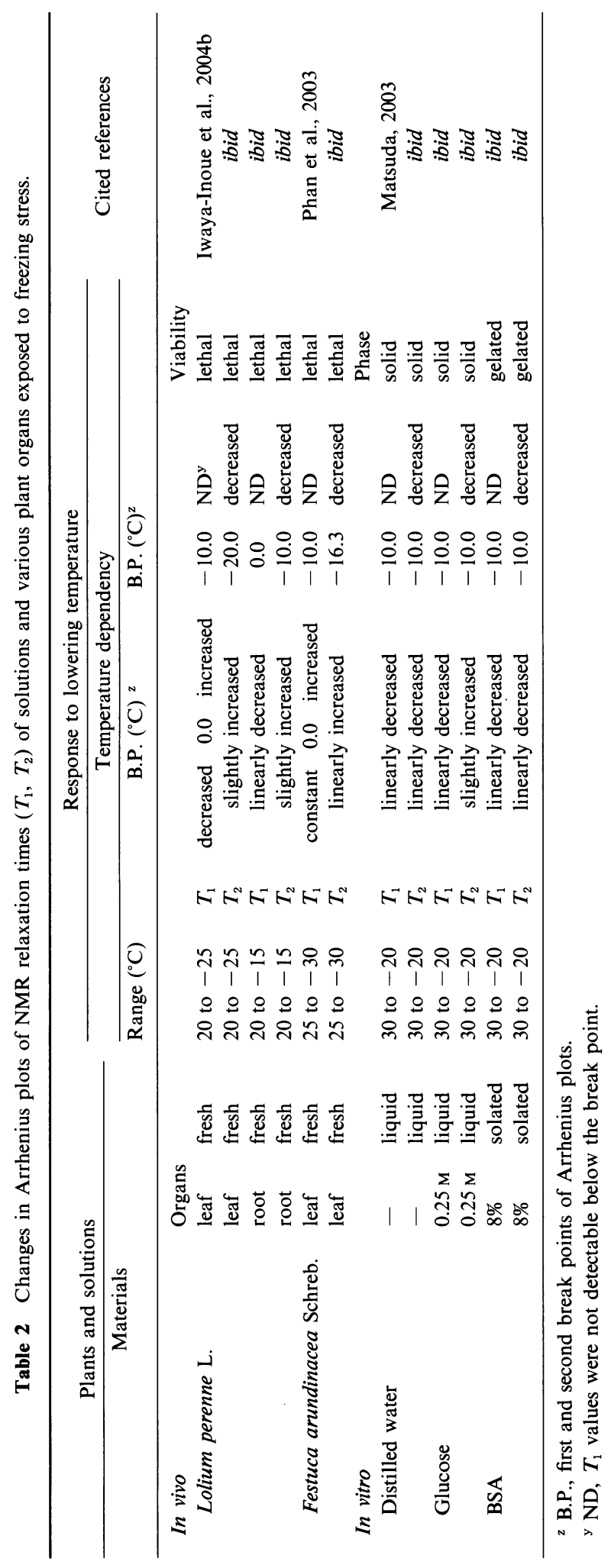




\section{PROLONGATION IN $T_{1}$ OF ORGANS EXPOSED TO CHILLING STRESS}

Long-term storage caused prolongation of $T_{1}$ in sweet potato (Ipomoea batatus Lam.) tubers (Iwaya-Inoue et al., 2004a). Initial $T_{1}$ values for the fresh tissues examined at $30^{\circ} \mathrm{C}$ were about $400 \mathrm{~ms}$, whereas those for the stored tuber tissues were about $700 \mathrm{~ms}$. There was not a clear thermal dependency on $T_{1}$ in the fresh tuber tissues, whereas a linear thermal dependency was observed in the case of $T_{1}$ in the stored tuber tissues of sweet potato (Table 1). The prolongation rate of $T_{1}$ values in the warming process of cool-warm cycle ( 20 to $0^{\circ} \mathrm{C}$ ) correlated with the degree of chilling damage or lesion in gloxinia leaf tissues (Kaku and Iwaya-Inoue, 1987).

In many cases of disordered tissues in animals, it has been shown that $T_{1}$ relaxation times are greatly enhanced in comparison to corresponding healthy ones (Damadian, 1971; Williams et al., 1980) and the theory was widely applied as MRI diagnosis (Podo et al., 1998 ; Hayes et al., 2002). And $T_{1}$ of water protons in biological systems may be influenced by a variety of changes in the conformational state of macromolecules, water-membrane and water-protein interactions (Chang et al., 1981; Mathur-De Vre, 1984). In woody plants, higher ratio of ion leakage was well associated with prolongation of $T_{1}$ in galled leaves invaded by insects (Kaku and Iwaya-Inoue, 1990). Ion leakage of the stored tuber tissues indicated about 70\%, thus the stored tissues were partly injured. It has been reported that $T_{1}$ values of chilling-sensitive Vigna radiata hypocotyls gradually increased after the tissues were exposed to $0^{\circ} \mathrm{C}$ for $1 \mathrm{~h}$ indicating reversible change while water content decreased slightly after the stress (Iwaya-Inoue et al., 1993). The distinct $T_{1}$ change in the slope after the "break" in Vigna two species occurred might suggest the beginning of the $T_{1}$ prolongation, assuming that the break does not occur and a linear drop of $T_{1}$ continues over the entire temperature range, and if the $T_{1}$ values between the actual data and the predicted value derived from the regression line for the first straight line segment are compared (Kaku and Iwaya-Inoue, 1988; IwayaInoue et al., 1989).

It is known that proteins are reversibly denatured at low temperatures as a result of weakening of hydrophobic bonds. A reversible change in conformation of $\mathrm{H}^{+}$-ATPase in the tonoplast of hypocotyls of Vigna radiata at $0^{\circ} \mathrm{C}$, may cause cytoplasmic acidification (Yoshida et al., 1989). There was a closed correlation between $\mathrm{pH}$ and $T_{1}$ in vitro; when $\mathrm{pH}$ of a solution of paramagnetic ions and protein, in particular, $\mathrm{Mn}^{2+}$ and bovine serum albumin (BSA), was reduced from 7.5 to 6.0, the $T_{1}$ value increased (Iwaya-Inoue et al., 1993). The range of $\mathrm{pH}$ values that affected $T_{1}$ significantly corresponded to the $\mathrm{pH}$ of the cytoplasm in Vigna cells in culture exposed to $0^{\circ} \mathrm{C}$ (Yoshida et al., 1989). Therefore, it seems likely that the gradual prolongation in $T_{1}$ for plant tissues exposed to chilling stress depends partly upon changes in cytoplasmic $\mathrm{pH}$.

\section{CHANGES IN NMR SPIN-SPIN RELAXATION TIMES $\left(T_{2}\right)$ IN ORGANS EXPOSED TO CHILLING STRESS}

$T_{2}$ was measured by the Carr-Purcell-Meiboon-Gill (CPMG) method with pulse $\left(90^{\circ} \mathrm{x}-\tau-180^{\circ} \mathrm{y}-2 \tau-180^{\circ} \mathrm{y}-2 \tau \cdots\right)$ sequence. $T_{2}$ values for the perennial ryegrass (Lolium perenne L.) leaves were almost constant or slightly increased with decreasing temperature between 20 and $0^{\circ} \mathrm{C}$ (Table 2, Fig. 1). Several components of $T_{2}$ for the tissues were also calculated from semi-log plots of ${ }^{1} \mathrm{H}$-NMR signal intensities using a curve fitting. $T_{2}$ values of two components in the leaves and roots showed no temperature dependency between 20 and $0^{\circ} \mathrm{C}$.

Additionally, a strong inverse relation between temperature and $T_{2}$ was observed at 
temperatures ranging from 30 and $0^{\circ} \mathrm{C}$ in fresh sweet potato tubers (Table 1). Initial $T_{2}$ values of the fresh sweet potato tuber tissues indicated around $100 \mathrm{~ms}$, whereas those of the stored tubers for one year at $15^{\circ} \mathrm{C}$ ranged between 200 and $300 \mathrm{~ms}$ (Iwaya-Inoue et al., 2004a). The long-term storage caused prolongation in sweet potato tubers. From these results, $T_{2}$ values as well as $T_{1}$ values in the sweet potato tubers increased with long-term storage. Electrolyte leakage indicated the stored sweet potato tubers were partly injured. A change in the slope of the Arrhenius plots of the $T_{2}$ values in fresh tubers was statistically investigated. As a result, a change of the slope in the $T_{2}$ of the fresh tissues was observed at about $14^{\circ} \mathrm{C}$, although there were no break points in the Arrhenius plots of $T_{2}$ in the dead tissues. It is known that the critical cold-storage temperature ranges between 10 and $15^{\circ} \mathrm{C}$ for sweet potato tubers (Ravi and Aked, 1996. references therein). The $15^{\circ} \mathrm{C}$-stored-tubers were partly injured by this method of evaluation, and the slope change occurred at about $14^{\circ} \mathrm{C}$ in the $T_{2}$ of the fresh tissues, which was consistent with the storage temperature. An Arrhenius plot of metabolic heat rate revealed a break in the line at $15^{\circ} \mathrm{C}$, suggesting the occurrence of a metabolic transition at this temperature (Queiroz et al., 2000).

$T_{2}$ changes in relation to chilling temperature were discussed in animal cells; when chicken eggs were stored according to the regulations between 5 and $8^{\circ} \mathrm{C}$ over 2 weeks storage, an increase of $T_{2}$ was observed in comparison to unchilled eggs (Schwagele et al., 2001). $T_{1}$ linearly decreased with decreases in temperature while $T_{2}$ of the $0.1 \mathrm{M}$ sucrose and maltose solutions slightly depended on temperature within the range of 30 to $0^{\circ} \mathrm{C}$, respectively. The difference between $T_{1}$ and $T_{2}$ observed in the sugar solutions was similar to those in the dead tuber tissues. In other words, the temperature dependency of $T_{2} \mathrm{~s}$ of the sugar solutions and the dead tissues appeared to respond to viscosity at higher temperatures. These results indicate that water mobility determined as $T_{2}$ was more suppressed at higher temperatures.

\section{PHASE CHANGE IN $T_{1}$ OF ORGANS EXPOSED TO FREEZING STRESS}

$T_{1}$ in sweet potato tuber tissues markedly decreased by treatment involving both freezing and thawing (Iwaya-Inoue et al., 2004a). Initial $T_{1}$ values for the fresh tuber tissues examined at $30^{\circ} \mathrm{C}$ ranged between about 300 and $500 \mathrm{~ms}$, whereas those for the frozen-thawed tissues were around $200 \mathrm{~ms}$. Since water contents in both the fresh and the frozen-thawed tissues of sweet potato tubers were about $65 \%$, shortening of $T_{1}$ did not depend on decrease in the water content. An extent of leakage of electrolytes was determined with an electrolyte conductivity meter and expressed as the percentage of the total electrolytes in each sample, measured after samples were killed by a cycle of freezing and thawing. An index has been reported of injury related to ionic conductance from freeze-stressed cabbage (Brassica oleracea L. Capitata cv.) (Manley and Hummel, 1996) and nitric oxide-stressed wheat leaves (Mata and Lamattina, 2001). Leakage of electrolytes in the frozen-thawed tuber tissues indicated $100 \%$, whereas that of fresh tissues was approximately 30\% (Iwaya-Inoue et al., 2004a). In the dead tissues a positive temperature dependency of the Arrhenius plots was clear in $T_{1}$ determined at temperatures ranging from 30 to $0^{\circ} \mathrm{C}$ (Table 1). The $T_{1}$ dependency in the dead plant tissues seems to solely reflect the mobility of water in the tissues as shown in vitro.

$T_{1}$ determination in fresh perennial ryegrass leaves could not be carried out at about -15 ${ }^{\circ} \mathrm{C}$ while $T_{1}$ in roots could not be determined below $-5^{\circ} \mathrm{C}$ (Table 2, Fig. 1). Similar tendency was observed in leaves of tall fescue (Festuca arundinacea Schreb.) (Phan et al., 2003). Both sugar and protein solutions adjusted to the concentrations in the ryegrass and tall fescue grass leaves were prepared. $T_{1} \mathrm{~s}$ of $0.25 \mathrm{M}$ sucrose and $8 \%$ BSA solutions linearly decreased with decrease in temperature and phase changes occurred at $-10^{\circ} \mathrm{C}$ and $T_{1}$ could not be determined at less than $-10^{\circ} \mathrm{C}$ (Matsuda, 2003). In addition, $T_{1}$ values in ryegrass leaves were markedly 
shorter than those in roots. Seasonal changes in $T_{1}$ were closely correlated with the water content and supercooling ability of azalea florets (Kaku et al., 1984). The water content in both ryegrass leaves and roots was about $89 \%$, and that of leaves and roots decreased to $82 \%$ and $83 \%$, respectively. Therefore, changes in $T_{1}$ of ryegrass organs as well as sweet potato tubers exposed to freezing stress could not be solely ascribed to the water content.

\section{ABRUPT DECREASE IN $T_{2}$ IN ORGANS EXPOSED TO FREEZING STRESS}

$T_{2}$ in the perennial ryegrass leaves gradually prolonged in the temperature range from 0 to $-20^{\circ} \mathrm{C}$ (Table 2, Fig. 1). Similar tendency was observed in $T_{2}$ of tall fescue leaves. A gradual increase in $T_{2}$ of long fraction and a linear decrease in $T_{2}$ of short fraction in ryegrass leaves were observed (Iwaya-Inoue et al., 2004b). Additionally, relative value of signal intensity in the long fraction gradually increased in the temperature range from 0 to $-20^{\circ} \mathrm{C}$. The $T_{2}$ in long fraction of the leaves is thought to be mainly associated with vacuole and the fraction with the short $T_{2}$ is thought to be associated with the cytosol and apoplastic region (Chen and Gusta, 1978). Difference in $T_{2}$ values of biological tissues is also interpreted in terms of the differences of the ratio of "free water" to "bound water" (Walter et al., 1989). The solid-echo $\left(90^{\circ}-\tau-90^{\circ}\right)$ method was also applied for $T_{2}$ measurements when $T_{2}$ values were below $1 \mathrm{~ms}$. Abrupt shortening of $T_{2}$ occurred in perennial ryegrass leaves at $-25^{\circ} \mathrm{C}$ and that in roots between -10 and $-15^{\circ} \mathrm{C}$. In addition, the similar phase change in $T_{2}$ of tall fescue occurred at about $-16^{\circ} \mathrm{C}$. The $T_{2}$ values in both long and short fractions of leaves decreased to about $600 \mu \mathrm{s}$ and $10 \mu \mathrm{s}$ at $-25^{\circ} \mathrm{C}$, respectively. $T_{2}$ value below $100 \mu \mathrm{s}$ is thought to be associated with water tightly bound to macromolecules in cells (Hills and Remigereau, 1997). The abrupt decrease in $T_{2}$ depended on decreases in $T_{2}$ values of two fraction components accompanied by a decrease in the signal intensity of long fraction component. On the other hand, $T_{2}$ in roots began to decrease at $-10^{\circ} \mathrm{C}$ and the relative value of signal intensity of the long $T_{2}$ fraction markedly decreased. In parenchyma tissue of apple, vacuolar peak of $T_{2}$ has

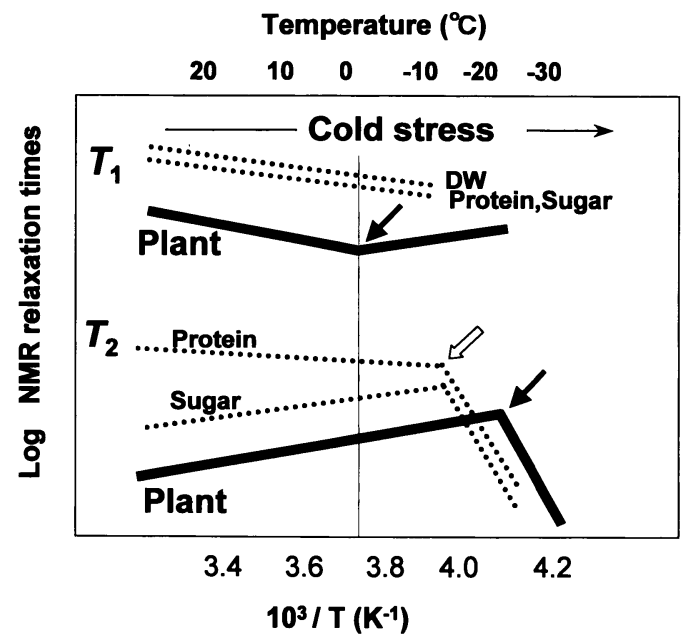

Fig. 1 Schematic profile of Arrhenius plots of $T_{1}$ and $T_{2}$ in crop plant organs and solutions exposed to cold stress. Solid lines indicate those of plant organs while broken lines indicate those in solutions. Since $T_{1}$ and $T_{2}$ in DW indicate same values in the temperature range, they are shown by one straight line. Black arrows indicate changing points observed in plant tissues and a white arrow indicates that of solutions. DW, distilled water ; Sugar, $0.25 \mathrm{M}$ glucose, $0.1 \mathrm{M}$ maltose and $0.1 \mathrm{~m}$ sucrose solutions; Protein, $8 \%$ bovine serum albumin (BSA) solution. 
vanished showing that the vacuolar compartment has frozen at $-3^{\circ} \mathrm{C}$, while the two peaks corresponding to the cytoplasm and cell wall compartments were observed indicating that these compartments remain unfrozen (Hills and Remigereau, 1997). Therefore, it indicated that vacuolar water in the leaf and root tissues disappeared at the abrupt changing point in $T_{2}$.

The leakage of electrolytes from the ryegrass leaf and root tissues after the abrupt decrease of $T_{2}$ which occurred at -25 and about $-15^{\circ} \mathrm{C}$, respectively, showed about $100 \%$ (IwayaInoue et al., 2004b). The leakage of electrolytes indicated these organs exposed to these subzero temperatures were severely damaged. In addition, activity of 2,3,5-triphenyltetrazolium chloride (TTC) reduction in ryegrass organs which reflected the viability of the tissues vanished. The marked shortening of $T_{2}$ in perennial ryegrass suggested that intracellular freezing occurred between -20 and $-25^{\circ} \mathrm{C}$ in leaves while it occurred between -10 and -15 ${ }^{\circ} \mathrm{C}$ in roots.

The shortening of $T_{2}$ has been attributed to a decrease in membrane permeability under freezing injury in wheat crowns (Chen and Gusta, 1978). The $T_{2}$ of cellular water is known to be dependent on plasmalemma and tonoplast permeability (Van As, 1992). $T_{2}$ values in the ryegrass roots were also longer than those in leaves as well as $T_{1}$. More restricted mobility of water in the leaves might play an important role against the freezing stress. These findings indicated that the abrupt $T_{2}$ decreasing was reflective of a supercooling ability in individual organs.

\section{CHANGES IN $T_{1}$ OF ORGANS EXPOSED TO HEAT STRESS}

$T_{1} \mathrm{~S}$ in leaves and roots of perennial ryegrass exposed to heat stress decreased in the temperature range between 20 and $50^{\circ} \mathrm{C}$ (Table 3, Fig. 2). $T_{1} \mathrm{~s}$ in the leaves were almost constant or slightly decreased from 20 to $35^{\circ} \mathrm{C}$ and a slope change occurred at $40^{\circ} \mathrm{C}$, while those in roots linearly decreased in temperatures ranging from 20 to $50^{\circ} \mathrm{C}$. Electrolyte leakage and TTC reduction indicated that leaf tissues have more heat resistance compared to roots (IwayaInoue et al., 2004b). On the other hand, epicotyls of pea (Pisum sativum L.) plants after the subsequent thermal hysteresis of $20-40^{\circ} \mathrm{C}$ cycles exhibited tissue necrosis (Iwaya-Inoue et al., 2004c). It has been reported that treatment at $40^{\circ} \mathrm{C}$ to pea plants led to a serious injury of the photosynthetic apparatus while the changes in $\mathrm{Chl}$ fluorescence parameters at $35^{\circ} \mathrm{C}$ were reversible (Georgieva and Lichtenthaler, 1999). $T_{1}$ values in intact pea epicotyl tissues exposed to $120^{\circ} \mathrm{C}$ for $15 \mathrm{~min}$ treatment markedly decreased from 1.2 to $0.7 \mathrm{~s}$ (Iwaya-Inoue et al., 2004c). The shortening of $T_{1}$ was also observed in the heat-denatured hypocotyls of mung bean (Iwaya-Inoue et al., 2000). $\quad T_{1} \mathrm{~s}$ for both $40^{\circ} \mathrm{C}$ - and $120^{\circ} \mathrm{C}$-treated pea epicotyls linearly decreased with decreasing temperature while it increased with increasing temperature between 20 and $40^{\circ} \mathrm{C}$. A slope change occurred at about $28^{\circ} \mathrm{C}$ and a prolongation in $T_{1}$ corresponding elevated temperature after the break point would reflect an occurrence of tissue injury. From these results, the temperature dependency in $T_{1}$ of the heat-denatured pea epicotyls as well as the frozen-thawed sweet potato tubers seems to solely reflect the mobility of water shown in vitro (Tables 1, 3).

On the contrary, it was indicated that molecular dynamics of water in pea epicotyls exposed to $30^{\circ} \mathrm{C}$ maintained the shortened values and was temperature-independent (IwayaInoue et al., 2004c). Furthermore, the shortening of $T_{1}$ was observed at $40^{\circ} \mathrm{C}$ in perennial ryegrass leaves (Table 3) and mung bean hypocotyls (Iwaya-Inoue et al., 1993). They exhibited no severe injury. Therefore, such findings suggested that adaptability for heat stress was accompanied by a shortening of $T_{1}$ values.

The water content of plant tissues is a main factor affecting water status in the tissues (Burke et al., 1974). $T_{1}$ values of mung bean seedlings exposed to $40^{\circ} \mathrm{C}$ for $4 \mathrm{~h}$ decreased by 


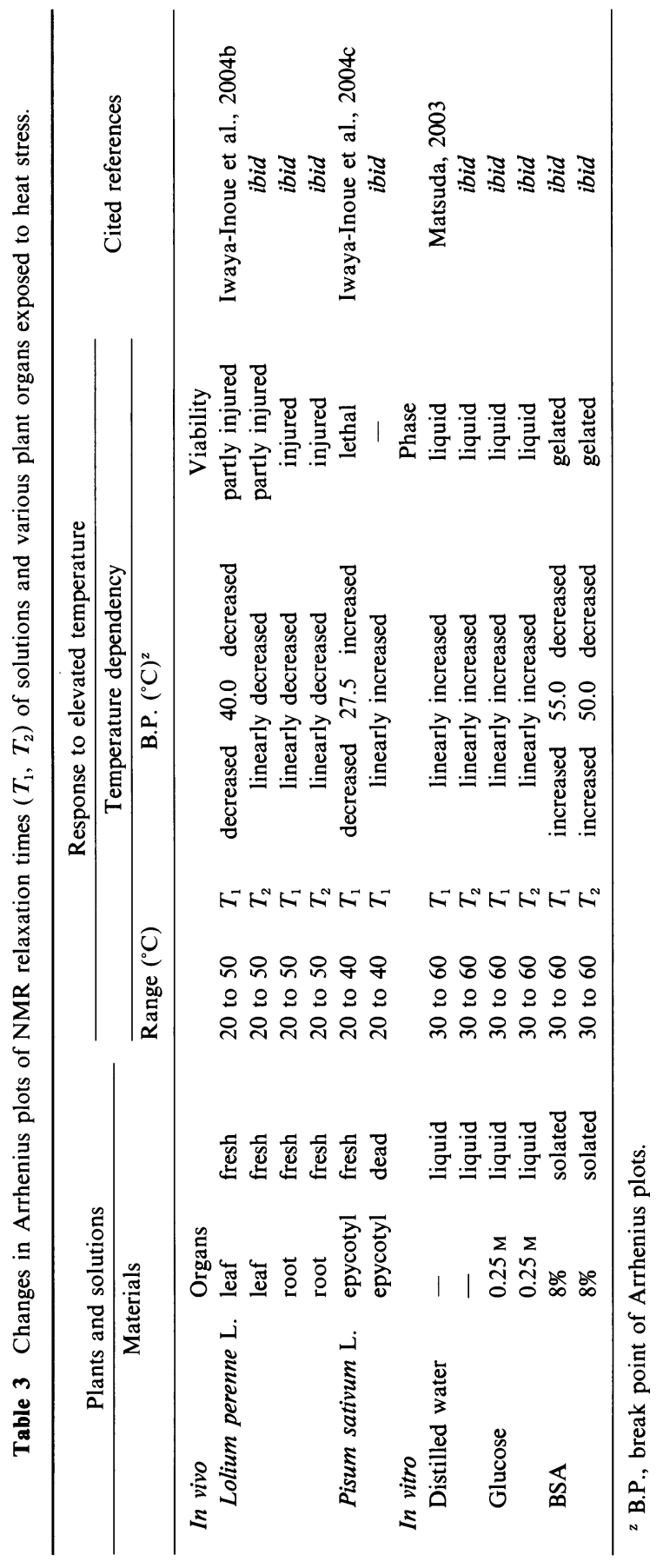


10 to $15 \%$, while the water content decreased slightly (by less than $2 \%$ ) after the heat stress (Iwaya-Inoue et al., 1993), which indicated the water content did not strongly affect $T_{1}$ in hypocotyls exposed to heat stress. In addition, the heat shock treatment $\left(40^{\circ} \mathrm{C}\right.$ for $\left.4 \mathrm{~h}\right)$ to the seedlings of Vigna radiata induced a $70 \mathrm{kDa}$ protein and the hypocotyls showed tissue viability (Iwaya-Inoue et al., 1993). In seedlings of the same species members of heat shock protein, HSP70 family, were induced by $41^{\circ} \mathrm{C}$ for $4 \mathrm{~h}$ (Kawata and Yoshida, 1988). In yeast cells HSP70 family might stabilize denatured proteins and it might play a role as a surfactant in cells (Komatsu et al., 1990). These results suggested that gradual shortening in $T_{1}$ and no temperature dependency in intact pea epicotyls exposed to $30^{\circ} \mathrm{C}$-thermal hysteresis might reflect cell adaptation to heat stress. In addition, a change in the slope of Arrhenius plots occurred at $40^{\circ} \mathrm{C}$ in $T_{1}$ of ryegrass leaf tissues would also indicate a primary response against heat stress. From these results, the early response in $T_{1}$ s of the epicotyl and leaf tissues was considered as a fast adaptation or mortality in cells to heat stress.

\section{CHANGE IN $T_{2}$ OF ORGANS EXPOSED TO HEAT STRESS}

$T_{2}$ values in both leaves and roots of the perennial ryegrass markedly decreased with an increase in temperature ranging from 20 to $50^{\circ} \mathrm{C}$ (Table 3, Fig. 2). Ion leakages in the leaves and roots after exposure to the heat stress were 27 and 56\%, respectively (Iwaya-Inoue et al., 2004b). The low leakage of electrolytes in leaves exposed to heat stress indicated there was no severe damage. These results suggested that leaves had more heat tolerance compared to roots. In general, plant roots are protected from cold and heat stresses more efficiently than the other organs, because the soil temperature is more stable than the air temperature as an environmental factor. It was reported that there was a steady decrease in $T_{2}$ for the major fraction for grape leaves with an increase in temperature and sharp decreases in $T_{2}$ at 48 and $45^{\circ} \mathrm{C}$, which correspond with the lethal temperature measured by both electrolyte leakage and TTC reduction (Abass and Rajashekar, 1991). In 8\% BSA solution, a marked decrease in Arrhenius plots of $T_{2}$ occurred at $50^{\circ} \mathrm{C}$ while a slight change occurred at $55^{\circ} \mathrm{C}$ in those of $T_{1}$. The BSA solution indicated gelatinization of soluble protein at the break points (Matsuda,

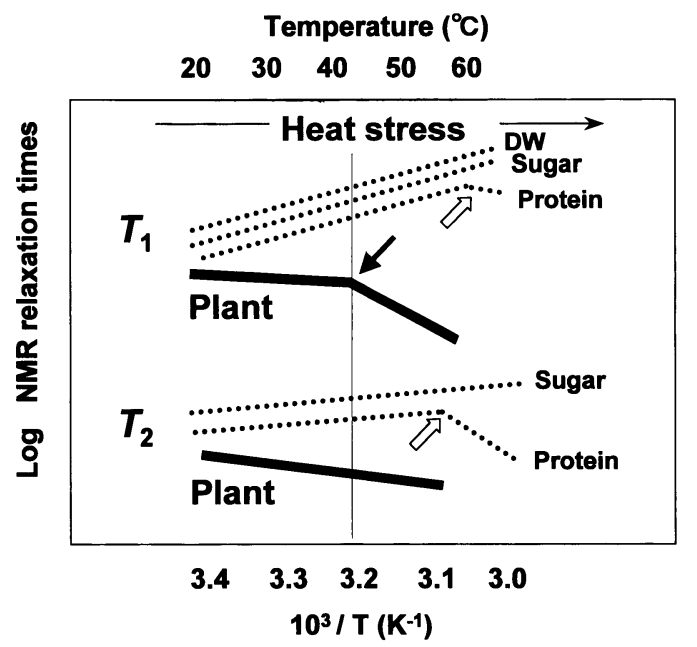

Fig. 2 Schematic profile of Arrhenius plots of $T_{1}$ and $T_{2}$ in crop plant organs and solutions exposed to heat stress. Lines and arrows are described in Fig. 1. Sugar, $0.25 \mathrm{M}$ glucose solution ; Protein, $8 \%$ BSA solution. 
2003). From these results, $T_{1}$ on heat response can be used as an indicator of the reversible change while $T_{2}$ can be used as that of the irreversible change in macromolecules and plant tissues.

\section{CONCLUSION}

Arrhenius plots of both $T_{1}$ and $T_{2}$ suggested that dynamic states of water reflected the difference in thermal response in hypocotyls, epicotyls, leaves, roots and tubers in various crop plants. These results underscore an importance of selecting temperature resistant cultivars for adaptation to cool and warm climates. Based on these results, it is possible to conclude that the break points in $T_{1}$ and $T_{2}$ of the Arrhenius plots of fresh tissues might be reflective of the physiological changes. Especially, $T_{1}$ can be used to detect response to mild stress and adaptation while $T_{2}$ is useful for viability assay to more severe stress to critical temperatures. In conclusion, Arrhenius plots of NMR relaxation times $\left(T_{1}, T_{2}\right)$ in various organs of crop plans provided sensitive and non-invasive way for evaluating tissue response to both cold and heat stresses.

We are thankful to Mr. Soichi Nagai, JEOL, Co., Ltd., Japan, for his technical support.

\section{REFERENCES}

Abass, M., Rajashekar, C. B. 1991. Characterization of heat injury in grapes using ${ }^{1} \mathrm{H}$ nuclear magnetic resonance methods. Plant Physiol. 96 : 957-961.

Akaike, H. 1971. Autoregressive model fitting for control. Ann. Inst. Statist. Math 23 : 163-180.

Budinger, T. F., Lauterbur, P. C. 1984. Nuclear magnetic resonance technology for medical studies. Science 226 : 288-298.

Burke, M. J., Bryant, R. G., Weiser, C. J. 1974. Nuclear magnetic resonance of water in cold acclimating red osier dogwood stem. Plant Physiol. 54 : 392-398.

Caldwell, C. R., Millard, M. M., Line, M. J. 1997. Magnetic resonance imaging of tissue-specific thermal responses of geranium stem in vivo. J. Thermal Biol. $22: 117-126$.

Casado, C. G., Heredia, A. 1999. Structure and dynamics of reconstituted cuticular waxes of grape berry cuticle (Vitis vinifera L.). J. Expt. Bot. 50: 175-182.

Chang, D. C., Misra, L. K., Beall, P. T., Funguy, R. C., Hazlewood, C. F. 1981. Nuclear magnetic resonance study of muscle water protons in muscular dystrophy of chickens. J. Cell Physiol. 107 : 139-145.

Chen, P. M., Gusta, L. V. 1978. Changes in membrane permeability of winter wheat cells following freeze-thaw injury as determined by nuclear magnetic resonance. Plant Physiol. 61 : 878-882.

Damadian, R. 1971. Tumor detection by nuclear magnetic resonance. Science 171: 1151-1153.

Ebdon, J. S., Gagne, R. A., Manley, R. C. 2002. Comparative cold tolerance in diverse turf quality genotypes of perennial ryegrass. Hortscience $37: 826-830$.

Farrar, T. C., Becker, E. D. 1971. Pulse and Fourier Transform NMR. Academic Press, New York.

Georgieva, K., Lichtenthaler, H. K. 1999. Photosynthetic activity and acclimation ability of pea plants to low and high temperature treatment as studied by means of chlorophyll fluorescence. J. Plant Physiol. 155 : 416-423.

Hayes, C., Padhani, A. R., Leach, M. O. 2002. Assessing changes in tumour vascular function using dynamic contrast-enhanced magnetic resonance imaging. NMR Biomed. 15 : 154-163.

Hills, B. P., Remigereau, B. 1997. NMR studies of changes in subcellular water compartmentation in parenchyma apple tissue during drying and freezing. Int. J. Food Sci. Tech. 32 : 51-61.

Ionenko, I. .F., Anisimov, A. V. 2001. Effect of water deficit and membrane destruction on water diffusion in the tissues of maize seedlings. Biol. Plant. $44: 247-252$.

Ishida, N., Kano, H., Kobayashi, T., Hamaguchi T., Yoshida, T. 1987. Estimation of biological 
activities by NMR in soybean seeds during maturation. Agr. Biol. Chem. 51 : 301-307.

Ishida, N., Koizumi, M., Kano, H. 2000. The NMR microscope : a unique and promising tool for plant science. Ann. Bot. $86: 259-278$.

Isobe, S., Ishida, N., Koizumi, M., Kano, H., Hazlewood, C. F. 1999 . Effect of electric field on physical states of cell-associated water in germinating morning glory seeds observed by ${ }^{1} \mathrm{H}-\mathrm{NMR}$. Biochim. Biophys. Acta 1426: 17-31.

Iwaya-Inoue, M., Sakaguchi, K., Kaku, S. 1989. Statistical studies using AIC methods to decide the question of "Break" or "Straight" in Arrhenius plots of water proton NMR relaxation times in chilling-sensitive Vigna and insensitive Pisum seedling. Plant Cell Physiol. 30 : 309-361.

Iwaya-Inoue, M., Yoshimura, K., Yamasaki, H., Kaku, S. 1993. Characteristic changes in relaxation times of water protons in Vigna radiata seedlings exposed to temperature stress. Plant Cell Physiol. 34: 705-711.

Iwaya-Inoue, M., Yoshimura, K., Otsubo, M., Yamasaki, H. 2000. Effects of oxygen stress on ${ }^{1} \mathrm{H}-\mathrm{NMR}$ relaxation time $\left(T_{1}\right)$ of Vigna radiata seedling. J. Fac. Agr. Kyushu Univ. $44: 249-256$.

Iwaya-Inoue, M., Tanaka, M., Fukuyama, M. 2002. Primary response in chilling sensitive crop leaves evaluated by Arrhenius plots of ${ }^{1} \mathrm{H}-\mathrm{NMR}$ relaxation times. J. Fac. Agr. Kyushu Univ. 47 : 21-27.

Iwaya-Inoue, M., Nonami, H. 2003. Effects of trehalose on flower senescence from the view point of physical states of water. Environ. Control in Biol. 41 : 3-15.

Iwaya-Inoue, M., Motooka, K., Ishibashi, Y., Fukuyama, M. 2003. Characteristic water status in dwarf pea in relation to drought resistance. J. Fac. Agr. Kyushu Univ. 48 : 29-38.

Iwaya-Inoue, M., Matsui, R., Sultana, N., Saitou, K., Sakaguchi, K., Fukuyama, M. 2004a. ${ }^{1}$ H-NMR method enables early identification of degeneration in the quality of sweet potato tubers. J. Agr. Crop Sci. 190 : 65-72.

Iwaya-Inoue, M., Matsui, R., Fukuyama, M. 2004b. Cold- or heat-tolerance of leaves and roots in perennial ryegrass determined by ${ }^{1} \mathrm{H}-\mathrm{NMR}$. Plant Pro. Sci. 7 : in press.

Iwaya-Inoue, M., Motooka, K., Nakamoto, H., Fukuyama, M. 2004c. Reversible or irreversible change of molecular dynamics of water in pea seedlings exposed to heat stress. J. Fac. Agr. Kyushu Univ. 49 : in press.

Kaku, S. 1993. Monitoring stress sensitivity by water proton NMR relaxation times in leaves of azaleas that originated in different ecological habitats. Plant Cell Physiol. 24 : 535-541.

Kaku, S., Iwaya-Inoue, M., Gusta, L. V. 1984. Relationship of nuclear magnetic resonance relaxation time to water content and cold hardiness in flower buds of evergreen azaleas. Plant Cell Physiol. 25 : 875-882.

Kaku, S., Iwaya-Inoue, M., Gusta, L. V. 1985. Estimation of the freezing injury in flower buds of evergreen azaleas by water proton nuclear magnetic resonance relaxation times. Plant Cell Physiol. 26: 1019-1025.

Kaku, S., Iwaya-Inoue, M. 1987. Estimation of chilling sensitivity and injury in gloxinia leaves by the thermal hysteresis of NMR relaxation-times of water proton. Plant Cell Physiol. 28 : 509-516.

Kaku, S., Iwaya-Inoue, M. 1988. Monitoring primary response to chilling stress in etiolated Vigna radiata and $V$. mungo seedlings using thermal hysteresis of water proton NMR relaxation times. Plant Cell Physiol. 29 : 1063-1068.

Kaku, S., Iwaya-Inoue, M. 1990. Factors affecting the prolongation of NMR relaxation times of water protons in leaves of woody plants affected by formation of insect galls. Plant Cell Physiol. 31 : 627637.

Kano, H., Ishida, N., Koizumi, M. 1997. Physical sates of water in plant tissues, possible probes for non-destructive quality estimation of agricultural products and foods by NMR. Recent Res. Dev. Agr. Biol. Chem. 1 : 125-145.

Kawata, T., Yoshida, S. 1988. Alterations in protein synthesis in vivo in chilling sensitive mung bean hypocotyls caused by chilling stress. Plant Cell Physiol. 29 : 1423-1427.

Komatsu, Y., Kaul, S. C., Iwahashi, H., Obuchi, K. 1990. Do heat shock protein provide protection against freezing? FEMS Microbiol. Lett. 72 : 159-162.

Levitt, J. 1980. Responses of Plants to Environmental Stress. 2nd ed., Vol. 1, Academic Press, New York, pp 23-64.

Lyons, J. M. 1973. Chilling injury in plants. Annu. Rev. Plant Physiol. 24 : 445-466.

Lyons, J. M., Raison, J. K. 1970 . Oxidative activity of mitochondria isolated from plant tissues sensitive 
and resistant to chilling injury. Plant Physiol. 45 : 386-389.

Maheswari, M., Joshi, D. K., Saha, R., Nagarajan, S., Gambhir, P. N. 1999. Transverse relaxation time of leaf water protons and membrane injury in wheat (Triticum aestivum L.) in response to high temperature. Ann. Bot. 84 : 741-745.

Manley, R. C., Hummel, R. L. 1996. Index of injury compared to tissue ionic conductance for calculating freeze damage of cabbage tissues. J. Amer. Soc. Hort. Sci. 121 : 1141-1146.

Martin, B. 1986. Arrhenius plots and the involvement of thermotropic phase transitions of the thylakoid membrane in chilling impairment of photosynthesis in thermophilic higher plants. Plant Cell Environ. 9: 323-331.

Mata, C. G., Lamattina, L. 2001. Nitric oxide induces stomatal closure and enhances the adaptive plant responses against drought stress. Plant Physiol. 126 : 1196-1204.

Mathur-De Vre, R. 1984. Biomedical implications of the relaxation behaviour of water related to NMR imaging. British J. Radiol. 57 : 955-976.

Matsuda, K. 2003. Temperature-stress responses in leaves of centipede grass (Eremochloa ophiuroides Munro [Hack] cv. Tifblair) evaluated by ${ }^{1} \mathrm{H}-\mathrm{NMR}$ relaxation times (in Japanese). Graduation Thesis, Kyushu University.

Phan, T., Fukuyama, M., Iwaya-Inoue, M. 2003. Effect of thermophile sewage sludge compost on the cold stress tolerance of tall fescue determined by ${ }^{1} \mathrm{H}-\mathrm{NMR}$. Cryobiol. Cryotechnol. 49: 81-88.

Podo, F., Henriksen, O., Bovee, W. M. M. J., Leach, M. O., Leibfritz, D., Decertaines, J. D. 1998. Absolute metabolite quantification by in vivo NMR spectroscopy - I - Introduction, objectives and activities of a concerted action in biomedical research. Mag. Reson. Imag. 16 : 1085-1092.

Queiroz, C. G. S., Mares-Guia, M. L., Magalhaes, A. C. 2000. Microcalorimetric evaluation of metabolic heat rates in coffee (Coffea arabica L.) roots of seedlings subjected to chilling stress. Thermochimica Acta 351 : 33-37.

Ravi, V., Aked, J. 1996. Review on tropical root and tuber crops. 2. Physiological disorders in freshly stored roots and tubers. Crit. Rev. Food Sci. Nut. 36 : 711-731.

Sabehat, A., Weiss, D., Lurie, S. 1998. Heat-shock proteins and cross-tolerance in plants. Physiologia Plantarum 103 : 437-441.

Schreiber, L. 2001. Effect of temperature on cuticular transpiration of isolated cuticular membrane and leaf discs. J. Exp. Bot. 52: 1893-1900.

Schreiber, L. 2002. Co-permeability of ${ }^{3} \mathrm{H}$-labelled water and ${ }^{14} \mathrm{C}$-labelled organic acids across isolated Prunus laurocerasus cuticles: effect of temperature on cuticular paths of diffusion. Plant Cell Environ. 25 : 1087-1094.

Schwagele, F., Poser, R., Krockel, L. 2001. Application of low-resolution NMR spectroscopy of intact eggs-Measurement of quality determining physical characteristics. Fleischwirtschaft 81 : 103-106.

Snaar, J. E. M., Van As, H. 1992. Probing water compartments and membrane permeability in plant cell by ${ }^{1} \mathrm{H}-\mathrm{NMR}$ relaxation measurements. Biophys. J. 63 : 1654-1658.

Steponkus, P. L. 1981. Responses to extreme temperature. Celllular and sub-cellular bases. In "Encyclopedia of Plant Physiology New Series” (ed. by Lange, O. L., Nobel, P. S., Osmond, C. B., Ziegler, H.), Vol. 12, Springer-Verlag, Berlin, pp 371-402.

Thomashow, M. F. 1999. Plant cold acclimation: Freezing tolerance genes and regulatory mechanisms. Annu. Rev. Plant Physiol. Plant Mol. Biol. 50 : 571-599.

Van As, H. 1992. NMR in horticulture : in situ plant water balance studies with NMR. Acta Hort. 304 : 103-112.

Van der Weerd, L., Claessens, M. M. A. E., Efde, C., Van As, H. 2002. Nuclear magnetic resonance imaging of membrane permeability changes in plants during osmotic stress. Plant Cell Environ. 25 : 1539-1549.

Vonwiren, N., Gibrat, R., Briat, J. F. 1998. In vitro characterization of iron-phytosiderophore interaction with maize root plasma membranes-evidences for slow association kinetics. Biochim. Biophys. Acta-Biomembranes 1371 : 143-155.

Waller, R. A., Sale, P. W. G. 2001. Persistence and productivity of perennial ryegrass in sheep pastures in south-western Victoria : a review. Aust. J. Expt. Agr. 41 : 117-144.

Walter, L., Balling, A., Zimmermann, U., Haase, A., Kuhn, W. 1989. Nuclear-magnetic-resonance imaging of leaves of Mesembryanthemum crystallinum L. plants grown at high salinity. Planta 178 : 524-530. 
Williams, E. S., Kaplan, J. I., Thatcher, F., Zimmerman, G., Knoebel, S. B. $1980 . \quad$ Prolongation of proton spin lattice relaxation times in regionally isochemic tissue from dog hearts. J. Nucl. Med. 21 : 449-453.

Wilson, J. M. 1987. Chilling injury in plants. In "The Effects of Low Temperatures on Biological Systems” (ed. by Grout, B. W. W., Morris, G. J.), Edward Arnold, London, pp 271-292.

Yoshida, M., Abe, J., Moriyama, M., Shimokawa, S., Nakamura, Y. 1997. Seasonal changes in the physical state of crown water associated with freezing tolerance in winter wheat. Physiol. Plant. 99 : 363-370.

Yoshida, S., Matsuura, C., Etani, S. 1989. Impairment of tonoplast $\mathrm{H}^{+}$-ATPase as an initial physiological response of cells to chilling in mung bean (Vigna radiata L. Wilczek). Plant Physiol. 89 : 634642. 